\title{
Daily patterns of plasma leptin in sheep: effects of photoperiod and food intake
}

\author{
M Marie ${ }^{1,3}$, P A Findlay ${ }^{1}$, L Thomas ${ }^{2}$ and C L Adam ${ }^{1}$ \\ ${ }^{1}$ Molecular Neuroendocrinology Group, Rowett Research Institute, Aberdeen Centre for Energy Regulation and Obesity, Bucksburn, Aberdeen AB21 9SB, UK \\ ${ }^{2}$ Molecular Physiology Group, Rowett Research Institute, Aberdeen Centre for Energy Regulation and Obesity, Bucksburn, Aberdeen AB21 9SB, UK \\ ${ }^{3}$ Sciences Animales, ENSAIA-INPL, BP 172, 54505 Vandoeuvre lès Nancy, France \\ (Requests for offprints should be addressed to C L Adam; Email: cla@rri.sari.ac.uk)
}

\begin{abstract}
Circulating concentrations of leptin in sheep correlate with body fatness and are affected by level of food intake and photoperiod. The present objective was to elucidate the short-term dynamics of leptin secretion. Frequent blood samples were taken over $48 \mathrm{~h}$ from 12 Soay rams after 16 weeks in short-day photoperiod (SD, $16 \mathrm{~h}$ darkness: $8 \mathrm{~h}$ light) with freely available food, and then after 16 weeks in long days (16 h light:8 h darkness) with food freely available (LD) or restricted to $90 \%$ maintenance (LDR) $(n=6 /$ group). During the second $24 \mathrm{~h}$ of sampling, half were food deprived ( $n=6$, SD and LD) and half had their meal times shifted ( $n=6, \mathrm{SD}$ and LDR). A homologous RIA was developed, using antibodies raised in chicken against recombinant ovine leptin, to measure plasma concentrations. Simultaneous $24 \mathrm{~h}$ profiles of plasma insulin, glucose and non-esterified fatty acids (NEFA) were measured. Plasma leptin was higher in LD than SD, and in
\end{abstract}

LD than LDR, associated with higher food intake, liveweight and body condition score (adiposity), but tended to be lower in LDR than SD, associated with lower food intake, liveweight and body condition score. There was no evidence for a circadian rhythm of plasma leptin, but clear evidence for post-prandial peaks of low amplitude (15$36 \%$ ) 2-8 h after meals given at normal and shifted times. Complete food deprivation caused a dramatic fall in plasma leptin to basal levels within $24 \mathrm{~h}$. There was a positive association of plasma leptin with plasma insulin, and negative association with NEFA, both between meals and during fasting. Thus, plasma leptin concentrations in sheep are sensitive to short-term changes in energy balance, as well as to long-term photoperiod-driven changes in food intake and adiposity.

Journal of Endocrinology (2001) 170, 277-286

\section{Introduction}

The adipose tissue hormone leptin provides feedback on peripheral energetic status to regulatory systems in the brain. Studies in laboratory rodents have revealed two distinct forms of leptin feedback, one encoding the level of body fat storage and the second, perhaps more important, signalling short-term or diurnal changes in food intake (Ahima \& Flier 2000). Daily patterns of leptin secretion in sheep have not previously been reported. Furthermore, given the contrasting nature of the ruminant digestive system, it is important to test the hypothesis that leptin in a ruminant species may be less sensitive in the short-term to the intake of food than in monogastric species.

Plasma concentrations of leptin correlate with body fatness in all species studied to date, including humans (Considine et al. 1996), rodents (Maffei et al. 1995), sheep (Blache et al. 2000, Delavaud et al. 2000), and cow (Ehrhardt et al. 2000). The level of food intake can also have major influence; for example, plasma leptin is reduced in sheep fed below liveweight-maintenance requirements (Bocquier et al. 1998, Delavaud et al. 2000) and in cattle subjected to a $48 \mathrm{~h}$ fast (Amstalden et al. 2000). It has also been shown that leptin gene expression in ovine adipose tissue (and by inference leptin biosynthesis) is reduced by underfeeding (Bocquier et al. 1998) and by a $48 \mathrm{~h}$ fast (Kumar et al. 1998). However, the dynamics of the leptin response to fasting in the ruminant and the factors that modulate leptin secretion in the short-term remain unclear.

A diurnal pattern of plasma leptin concentrations has been described in man (Sinha et al. 1996, Langendonk et al. 1998), but this is clearly entrained to the pattern of intake of meals rather than to a circadian oscillator (Schoeller et al. 1997). Leptin concentrations rise some time after ingestion of food and are at their nadir in the early morning before a meal has been taken (Schoeller et al. 1997). Similarly, there is a diurnal pattern of circulating leptin, associated with the pattern of feeding and characterised by a nocturnal peak, in rats (Saladin et al. 
1995) and mice (Ahren 2000). In contrast, Blache et al. (2000) found no diurnal or meal-related fluctuations in plasma leptin in rams, attributing the apparent species difference to differences in nutritional physiology between monogastrics and ruminants.

Although photoperiod has been reported to influence plasma leptin in sheep (Bocquier et al. 1998), there are no data comparing diurnal patterns of leptin concentrations between long and short daylengths.

In rats, the intake of food raises circulating leptin by transiently increasing leptin gene expression in adipose tissue (Saladin et al. 1995). This effect is mimicked by a single insulin injection, with or without concomitant hypoglycaemia, suggesting that the increase in leptin mRNA following ingestion of a meal may be mediated by direct actions of insulin on the adipocyte (Saladin et al. 1995). Insulin administration increased plasma leptin levels in rats within $4 \mathrm{~h}$ (Hardie et al. 1996), but not in sheep within $2 \mathrm{~h}$ (Kauter et al. 2000). However, the interrelationships between endogenous leptin, insulin and ingestion of food remain unresolved for any ruminant species.

In the present study we aimed to elucidate diurnal patterns of plasma leptin concentrations in the ruminant and how these are modulated by nutritional and photoperiodic status. Since validated assays for ovine leptin were unavailable at the outset of this study (Blache et al. 2000, Delavaud et al. 2000, Ehrhardt et al. 2000), we first developed an RIA specific to ovine leptin for use in our laboratory. In seasonal species like sheep, photoperiod influences appetite and body weight, and thereby interacts with imposed nutritional treatments. We therefore aimed to compare, firstly, sheep fed freely in short daylength (SD) with both freely fed sheep in long daylength (LD) and sheep in LD given a daily intake of food restricted to that normally freely consumed in SD (LDR). The second comparison, between LD and LDR sheep, examined the effect of food restriction. Further, we examined the effects on diurnal leptin profiles of either a $24 \mathrm{~h}$ fast or a shift in the timing of meals within both photoperiods. Throughout the study, we compared and contrasted with leptin profiles the simultaneous diurnal patterns of plasma insulin, glucose and non-esterified fatty acids (NEFA), since these are recognised short-term indicators of metabolic state.

\section{Materials and Methods}

\section{Animals and treatments}

Adult Soay rams were individually housed in artificial light-controlled rooms, allowing contact by smell, touch and vision. They were exposed for 16 weeks to short-day photoperiod (SD, $8 \mathrm{~h}$ light:16 h darkness) followed by 16 weeks to long-day photoperiod (LD, $16 \mathrm{~h}$ light: $8 \mathrm{~h}$ darkness). In SD, all were fed freely $(n=12)$. In LD, half of the sheep continued on free feeding (LD, $n=6$ ) while the remainder received restricted feeding (approximately 90\%

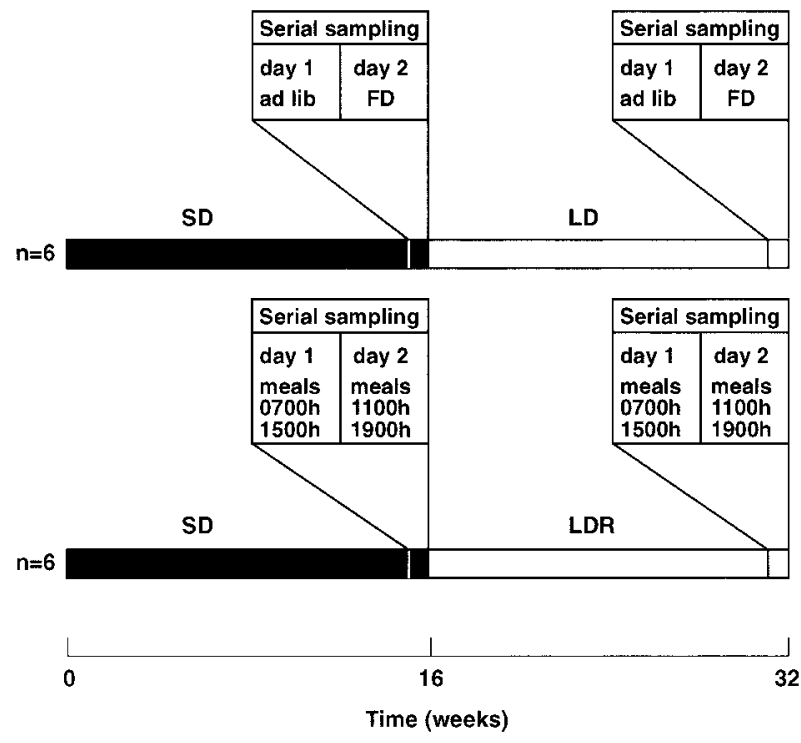

Figure 1 Experimental design. Sheep were kept for 16 weeks in short days (SD, $8 \mathrm{~h}$ light:16 h darkness; solid bar) followed by 16 weeks in long days (LD, $16 \mathrm{~h}$ light:8 h darkness; open bar). All were fed freely (ad lib) in SD. In LD, one group received food freely and the other group was given restricted food (LDR). Food was given in two meals daily. Serial blood samples were taken over $48 \mathrm{~h}$ during which SD/LD sheep had freely available food on day 1 but were food deprived (FD) on day 2, and SD/LDR sheep had meal times shifted on day 2.

liveweight maintenance; LDR, $n=6$ ) (Fig. 1). The food (complete diet comprising 50\% chopped hay, 30\% rolled barley, 9\% white fishmeal, and containing approximately $10 \mathrm{MJ}$ metabolisable energy $/ \mathrm{kg}$ dry matter $(\mathrm{DM})$ ) was given in two equal amounts at $0700 \mathrm{~h}$ and $1500 \mathrm{~h}$ (GMT). Sheep on free feeding had a 10\% refusal margin, and intakes were measured daily. Liveweight and body condition score (BCS, scale 1 (thin)-5 (fat), Russel et al. (1969)) were measured once a fortnight.

\section{Forty-eight hour sampling protocol}

During the final week of each photoperiod, i.e. during weeks 16 and 32 of the experiment, blood was taken from an indwelling jugular catheter at intervals of 30-60 min over $48 \mathrm{~h}$, starting at $0500 \mathrm{~h}$ ( $2 \mathrm{~h}$ before lights-on) on day 1. On day 1 , all sheep received their food in two feeds as usual at $0700 \mathrm{~h}$ and $1500 \mathrm{~h}$. The group receiving food freely in both photoperiods had all food removed at $2300 \mathrm{~h}$ (i.e. after $18 \mathrm{~h}$ of sampling) and received no meals thereafter on day $2(n=6)$. The sheep in the other group, freely receiving food in SD and restricted food in LD (LDR), had their two meal times shifted by $4 \mathrm{~h}$ to $1100 \mathrm{~h}$ and $1900 \mathrm{~h}$ on day $2(n=6)$ (Fig. 1).

During the hours of darkness, dim red light was used to facilitate sampling without disturbing the light-darkness 
cycle. Blood was collected into heparinised tubes and plasma stored at $-20{ }^{\circ} \mathrm{C}$ until assayed.

All experimental procedures were licensed under the UK Animals (Scientific Procedures) Act of 1986 and received ethical approval from the Rowett Research Institute's Ethical Review Committee.

\section{Leptin assay}

Recombinant ovine leptin (Gertler et al. 1998) was used for antibody preparation, tracer and standard curve. The antibody (Genosys, Cambridge, UK) was raised in chicken using six fortnightly injections giving a total dose of $1 \mathrm{mg}$ ovine leptin in complete, followed by incomplete, Freund's adjuvant. Eggs produced 77 to 101 days following primary immunisation were collected, immunoglobulins extracted from the yolk using the EGGstract method (Promega, Southampton, UK) and reconstituted in equal volume of buffer $(0.01 \mathrm{M}$ potassium phosphate, $0.1 \mathrm{M}$ $\mathrm{NaCl}, 50 \mathrm{mg} / \mathrm{l}$ gentamicin, $\mathrm{pH} 7 \cdot 4)$. Ovine leptin (5 $\mu \mathrm{g} /$ $5 \mu \mathrm{l})$ was mixed with $5 \mu \mathrm{l}$ phosphate buffer $(0.5 \mathrm{M}$, pH $7 \cdot 5)$ and $0 \cdot 5 \mathrm{mCi}(5 \mu \mathrm{l})$ of $\mathrm{Na}^{125}$ I solution (ICN Biomedicals Ltd, Thame, Oxon, UK), and allowed to react for $30 \mathrm{~s}$ with $25 \mu \mathrm{g}(5 \mu \mathrm{l})$ chloramine $\mathrm{T}$ (Hunter \& Greenwood 1962). The reaction was halted by the addition of $200 \mu \mathrm{l}$ sodium metabisulphite $(12 \mathrm{mg}$ in $10 \mathrm{ml} 0.05 \mathrm{M}$ phosphate buffer) and $100 \mu \mathrm{l}$ potassium iodide $(10 \mathrm{mg}$ in $10 \mathrm{ml}$ $0.05 \mathrm{M}$ phosphate buffer). The iodination products were eluted with $0.05 \mathrm{M}$ phosphate buffer containing 0.5\% BSA on a Sephadex G25 column and $150 \mu$ fractions were collected. A typical iodination gave a specific activity of $63 \mu \mathrm{Ci} / \mu \mathrm{g}$. Fractions corresponding to the first part of the first peak were kept and binding to excess first antibody (1/125 dilution) was $82 \cdot 6 \%$.

The assay buffer was $0 \cdot 05 \mathrm{M}$ phosphate, $0 \cdot 15 \mathrm{M} \mathrm{NaCl}$, $5 \mathrm{~g} / 1 \mathrm{BSA}, 100 \mu \mathrm{l} / 1$ Tween-20, $0 \cdot 025 \%$ sodium azide, $\mathrm{pH}$ $7 \cdot 4$. One hundred microlitre samples, standard (5$0.0195 \mathrm{ng} /$ tube in nine serial dilutions in assay buffer) or assay buffer (zero binding $\left(\mathrm{B}_{0}\right)$ and non-specific binding (NSB) tubes) were pre-incubated for $48 \mathrm{~h}$ at room temperature with $500 \mu \mathrm{l}$ first antibody diluted at 1/2000 in assay buffer. Iodinated leptin (8000 c.p.m.) in $100 \mu \mathrm{l}$ buffer was added and incubated for $24 \mathrm{~h}$ at $4{ }^{\circ} \mathrm{C}$. Then, $500 \mu \mathrm{l}$ buffer containing the second antibody (sheep antichicken; ref. S253-205, Diagnostics Scotland, Carluke, Lanarkshire, UK) at $1 / 100$ dilution and $6 \mu \mathrm{g}$ normal chicken immunoglobulin were added and incubated at $4{ }^{\circ} \mathrm{C}$ for 3 days. One millilitre polyethylene glycol $(4 \%$ PEG 8000) was added and the tubes centrifuged at $4{ }^{\circ} \mathrm{C}$ for $30 \mathrm{~min}$ at $2250 \mathrm{~g}$. Supernatants were discarded by decantation and ${ }^{125} \mathrm{I}$ in the pellets was counted for 2 min.

A typical standard curve is shown in Fig. 2a. The NSB count was $2 \cdot 2 \%$ of the total count, and the absolute binding for $\mathrm{B}_{0}$ was $12 \cdot 3 \%$. Sensitivity was $45 \mathrm{pg} /$ tube $(0 \cdot 45 \mathrm{ng} / \mathrm{ml})$. Parallelism of the standard curve with serial dilutions of ovine, caprine and bovine plasma samples
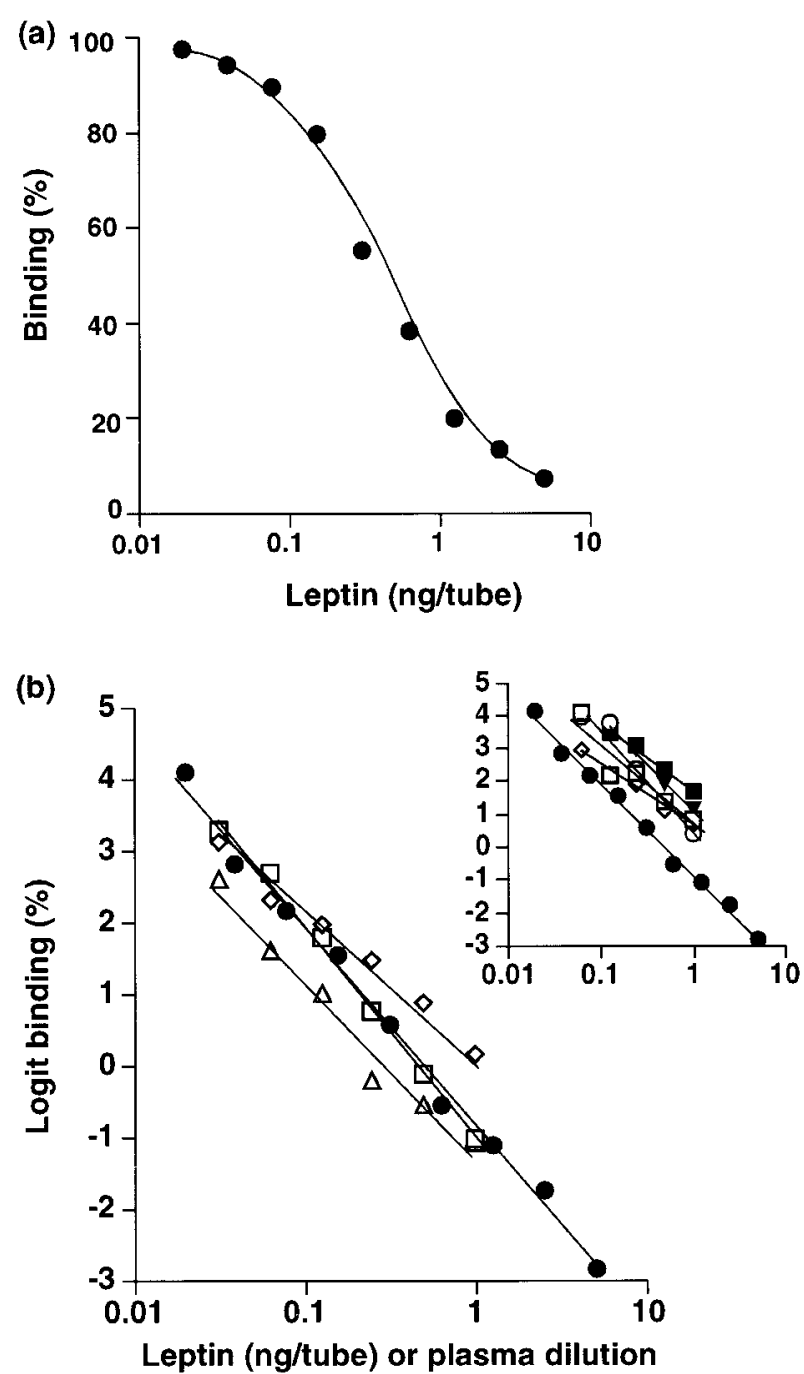

Figure 2 (a) Typical standard curve for leptin assay; (b) linear logit representation of recombinant ovine leptin standard curve (solid symbols) with parallelism shown by serial dilutions of three ovine plasma samples (open symbols), and (insert) three caprine (open symbols) and two bovine (solid symbols) plasma samples.

was demonstrated (Fig. 2b). The coefficient of variation $(\mathrm{CV})$ observed for six ovine plasma samples with leptin concentrations from $3 \cdot 4$ to $16 \cdot 1 \mathrm{ng} / \mathrm{ml}$ was $12 \%$ $(6 \cdot 7-13 \cdot 3 \%)$ for intra-assay and $16 \%(13 \cdot 3-21 \cdot 3 \%)$ for inter-assay repeatability.

All chemicals and reagents were obtained from Sigma UK Ltd (Poole, Dorset, UK) unless indicated otherwise.

\section{Insulin, glucose and NEFA determinations}

Insulin in plasma was measured using the RIA described by MacRae et al. (1991). Inter- and intra-assay CV values were $9 \cdot 2$ and $5 \cdot 2 \%$ respectively, and assay sensitivity was $2 \mu \mathrm{IU} / \mathrm{ml}$. 
Table 1 Mean ( \pm S.E.M.) liveweight (LW), BCS, food intake and plasma concentrations of leptin, insulin, glucose and NEFA (averaged over day 1 of intensive sampling) for sheep after 16 weeks with freely available food in short days (SD), and the same sheep after 16 weeks with freely available food in long days (LD) or restricted food (90\% liveweight maintenance) in LDs (LDR) ( $n=6 /$ group). ANOVA was used to compare photoperiods within groups using animals as blocks (SD vs LD; SD vs LDR) and to compare groups within photoperiod (LD vs LDR)

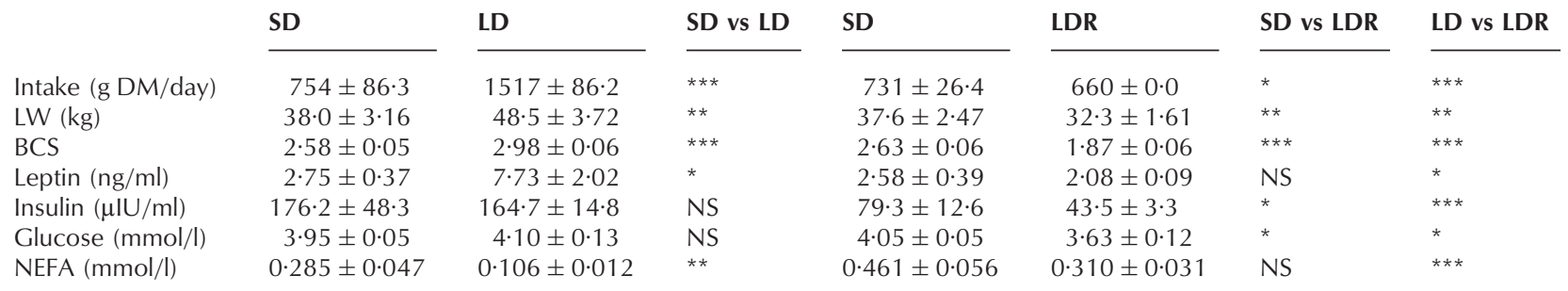

${ }^{* * *} P<0 \cdot 001,{ }^{* *} P<0 \cdot 01,{ }^{*} P<0 \cdot 05$, NS non-significant.

Glucose and NEFA in plasma were determined by fully automated KONE Analyser methods of Peterson \& Young (1968) and Matsubara et al. (1983) respectively. The sensitivity of the glucose assay was $0.34 \mathrm{mmol} / 1$ and the intra- and inter-assay CV values were 0.35 and $2.3 \%$ respectively. The sensitivity of the NEFA assay was $0.04 \mathrm{mmol} / 1$ and the intra- and inter-assay $\mathrm{CV}$ values were $4 \cdot 0$ and $2 \cdot 0 \%$ respectively.

\section{Statistical analysis}

Group mean comparisons (for liveweight, BCS, food intake and plasma concentrations, as shown in Table 1) were analysed by ANOVA, comparing the two groups of different sheep within LD photoperiod (LD vs LDR), and comparing photoperiods within groups of the same animals (SD vs LD and SD vs LDR) using animals as blocks (Genstat 5, Version 4-1) (Genstat 5 Committee 1993). NEFA, insulin, and leptin values in LD were logtransformed in order to normalise residuals. ANOVA was used to compare average leptin values over three defined time periods within $24 \mathrm{~h}$ in each photoperiod, again using animals as blocks (Genstat 5, Version 4-1) (Table 2a). Cosinor analysis was undertaken to explore further any diurnal rhythmicity in plasma leptin concentrations, fitting the function $[\mathrm{M}+\mathrm{A} \times \sin (0 \cdot 2618 \times \mathrm{t}+\mathrm{P})]$, where $\mathrm{M}$ is the $24 \mathrm{~h}$ mean value $(\mathrm{ng} / \mathrm{ml}), \mathrm{A}$ is the amplitude $(\mathrm{ng} / \mathrm{ml}), \mathrm{t}$ is the time (h) and $\mathrm{P}$ is the phase (radians); the significance of this model for each group/day was assessed by a Rayleigh test (Mardia 1972) (Table 2b).

Time-course data (Figs 3 and 4) were analysed by the residual maximum likelihood (REML) method, using Genstat 5 Version $4 \cdot 1$, and under guidance from Biomathematics \& Statistics Scotland (BioSS, RRI Group, Aberdeen, UK). In order to take into account correlations between successive measures done on each individual, covariance was modelled by an auto-regressive procedure (Littell et al. 1998). The effect of time was tested by a Wald test, using a Chi square statistic; differences between means were compared by a $t$-test to standard errors of differences specific for each compared pair of means. In this way, the timings of significant increases and decreases in concentrations were detected for each metabolite and hormone during the $48 \mathrm{~h}$ sampling periods.

\section{Results}

\section{Effect of photoperiod and food restriction}

Voluntary food intake doubled in LD compared with SD and this was associated with an increase in liveweight and BCS (Table 1). Plasma leptin increased by $180 \%$ and plasma NEFA concentrations decreased whereas plasma insulin and glucose were not changed (Table 1).

Food intake of LDR sheep was $90 \%$ of that consumed in SD and they experienced a significant loss of weight and BCS (Table 1). Plasma insulin and glucose were reduced in LDR compared with SD; furthermore, leptin concentrations tended to be reduced whereas NEFA tended to be increased, although these did not reach significance (Table 1).

Compared with LD sheep, LDR animals had lower food intake, liveweight and BCS, and reduced plasma leptin, insulin and glucose but higher plasma NEFA concentrations (Table 1).

Short-term patterns of circulating leptin, insulin, glucose and NEFA

Effect of meals and time of day Statistical (REML) analysis of the patterns of plasma concentrations during day 1 of intensive sampling were undertaken in both SD groups together $(n=12)$, and LD and LDR groups $(n=6 /$ group). The timing of a significant increase/decrease in concentrations identified by REML analysis was defined at the first significantly different value in a series, and significant concentration peaks and nadirs were detected. 
In addition, $24 \mathrm{~h}$ leptin concentrations for each individual were both averaged over three $8 \mathrm{~h}$ periods, then group means compared by ANOVA to detect overall day-night differences, and subjected to cosinor analysis to detect rhythmicity, giving amplitude and time of zenith (acrophase).

Metabolic parameters followed a pattern clearly related to meal intake (Figs 3 and 4). NEFA levels decreased during the first 30-60 min after each meal in all groups, but less so in LD when the basal levels were lower. Thereafter, plasma NEFA increased $4 \mathrm{~h}$ (in LDR), 6-10 h (in SD) or 12-14 h (in LD) after meals. A post-prandial increase of insulin was observed in the first 30-60 min. This was followed by a decrease starting as soon as the second hour after the meal, and plasma glucose was subsequently reduced in proportion to the insulin increases.

In SD, plasma leptin concentrations increased significantly (from $2.43 \mathrm{ng} / \mathrm{ml}$ ) at $6 \mathrm{~h}$ after the first meal to a maximum $(2.85 \mathrm{ng} / \mathrm{ml})$ at $8 \mathrm{~h}$, or from $2.55 \mathrm{ng} / \mathrm{ml}$ at $4 \mathrm{~h}$ to a maximum $3.22 \mathrm{ng} / \mathrm{ml}$ at $5 \mathrm{~h}$ after the second meal (Figs 3 and 4). Values thereafter decreased during the latter part of the dark phase and the onset of the light phase to a nadir at $2.5 \mathrm{~h}$ following the first meal. Thus during the first $8 \mathrm{~h}$ of the night (but not during the last $8 \mathrm{~h}$ of the night), plasma leptin values were higher than daytime concentrations $(P<0 \cdot 01)$ (Table $2 a)$. The cosinor model for these data was not significant (Table $2 b)$.

In LDR, plasma leptin increased significantly at $1.5 \mathrm{~h}$ (from $1.95 \mathrm{ng} / \mathrm{ml}$ ) to a maximum $(2.53 \mathrm{ng} / \mathrm{ml})$ at $3 \mathrm{~h}$ after the first meal, or at $1 \mathrm{~h}(1.92 \mathrm{ng} / \mathrm{ml})$ to a peak at $2 \mathrm{~h}$ $(2.62 \mathrm{ng} / \mathrm{ml})$ after the second meal (Fig. 3). Values decreased following the post-prandial peaks to nadirs at the onset of the second meal and at 5-9 h after the second meal (i.e. at the end of light/start of dark phase). Night-time leptin values were therefore less than during the first part $(P<0.001)$ but not the second part of the day in LDR, and the acrophase $(P<0.001)$ was during daytime at $4.8 \mathrm{~h}$ after lights-on (Table $2 a$ and $b$ ).

In LD, significant increases in plasma leptin were seen at $2.5 \mathrm{~h}$ after the first meal, from $6.63 \mathrm{ng} / \mathrm{ml}$ to a maximum $(7.62 \mathrm{ng} / \mathrm{ml})$ at $6 \mathrm{~h}$, and at $2 \mathrm{~h}$ after the second meal $(6.58 \mathrm{ng} / \mathrm{ml})$ to a maximum at $3 \mathrm{~h}(7.53 \mathrm{ng} / \mathrm{ml})$ (Fig. 4). There were no day-night differences in plasma leptin detected in LD, and the cosinor model was not significant (Table $2 a$ and $b$ ).

The above data show that the absolute variations of plasma leptin in all three treatments were of low amplitude, $0.72 \pm 0.09 \mathrm{ng} / \mathrm{ml}$ (range $0.42-1.0 \mathrm{ng} / \mathrm{ml}$ ), representing increments of $23 \pm 3 \cdot 7 \%$ (14-36\%), with these peaks occurring $2-8 \mathrm{~h}$ after a meal.

Effect of shifting the meal times For this analysis, plasma concentrations in SD/LDR sheep $(n=6)$ were examined by REML during both days of intensive sampling in SD and LDR to reveal whether the metabolic parameters, including leptin, were affected by the altered timing of meals during day 2 . The effects of meals during day 1 are described above. In addition, concentrations were averaged over three periods of 8,8 and 6 h duration, starting at lights-on, in order to detect overall day-night differences.

As on day 1, plasma NEFA concentrations decreased immediately, insulin increased and there was a subsequent decrease in plasma glucose after each meal on day 2 in both SD and LDR (Fig. 3).

In SD, leptin increased $2 \mathrm{~h}$ after the first meal on day 2 $(P<0 \cdot 001)$ and $1 \mathrm{~h}$ after the second meal $(P<0 \cdot 001)$ to peaks at $4 \mathrm{~h}$ after each meal. These increases therefore occurred sooner post-prandially than on day 1 . The second leptin peak on day 2 was higher than that on day 1 and was followed by sustained elevated values for the remainder of the sampling period (Fig. 3). Thus, following the meal shift in SD, overall plasma leptin was elevated in the latter part of the night compared with early night- and daytime values $(P<0 \cdot 001$, Table $2 a)$. Furthermore, the corresponding cosinor acrophase was shifted to the latter part of the night on day $2(P<0 \cdot 01$, Table $2 b)$.

In LDR, however, in contrast to day 1 , there were no significant changes in plasma leptin over time on day 2 (Fig. 3). There were therefore no significant day-night differences in concentrations and the cosinor model was not significant (Table $2 a$ and $b$ ).

Effect of food deprivation Fasting induced a steady decline in plasma leptin concentrations, starting from the peak after the last meal, to basal levels of 1.50-1.75 $\mathrm{ng} / \mathrm{ml}$ at $26 \mathrm{~h}$ after the last meal in SD, and of $2 \mathrm{ng} / \mathrm{ml}$ at $33 \mathrm{~h}$ after the last meal in LD (Fig. 4). Insulin concentrations decreased similarly to basal values, with the decline initiated within $2 \mathrm{~h}$ of the last meal in LD. NEFA remained at high levels during the food-deprivation period. For each individual in LD, insulin, NEFA and leptin patterns on day 2 presented a clear departure from values observed during day 1 . Relative to basal values observed before the last meal on day 1 , a significant decrease in insulin concentrations was observed at $5.5 \pm 0.96 \mathrm{~h}$ after the last meal, before the increase in NEFA (at $12.7 \pm 1.2 \mathrm{~h}, P<0.001$ ) and the fall in leptin concentrations (at $15 \cdot 8 \pm 2.3 \mathrm{~h}, P<0 \cdot 01$ ). In individual sheep, the NEFA increase preceded or coincided with the initiation of the leptin increase.

\section{Discussion}

The present study provides the first evidence for the existence of short-term patterns of plasma leptin concentrations in a ruminant species, superimposed on the long-term regulation of leptin secretion by nutrition and photoperiod.

Photoperiod clearly affected voluntary food intake, liveweight and adiposity (BCS) in the present Soay sheep, 
(a) SD
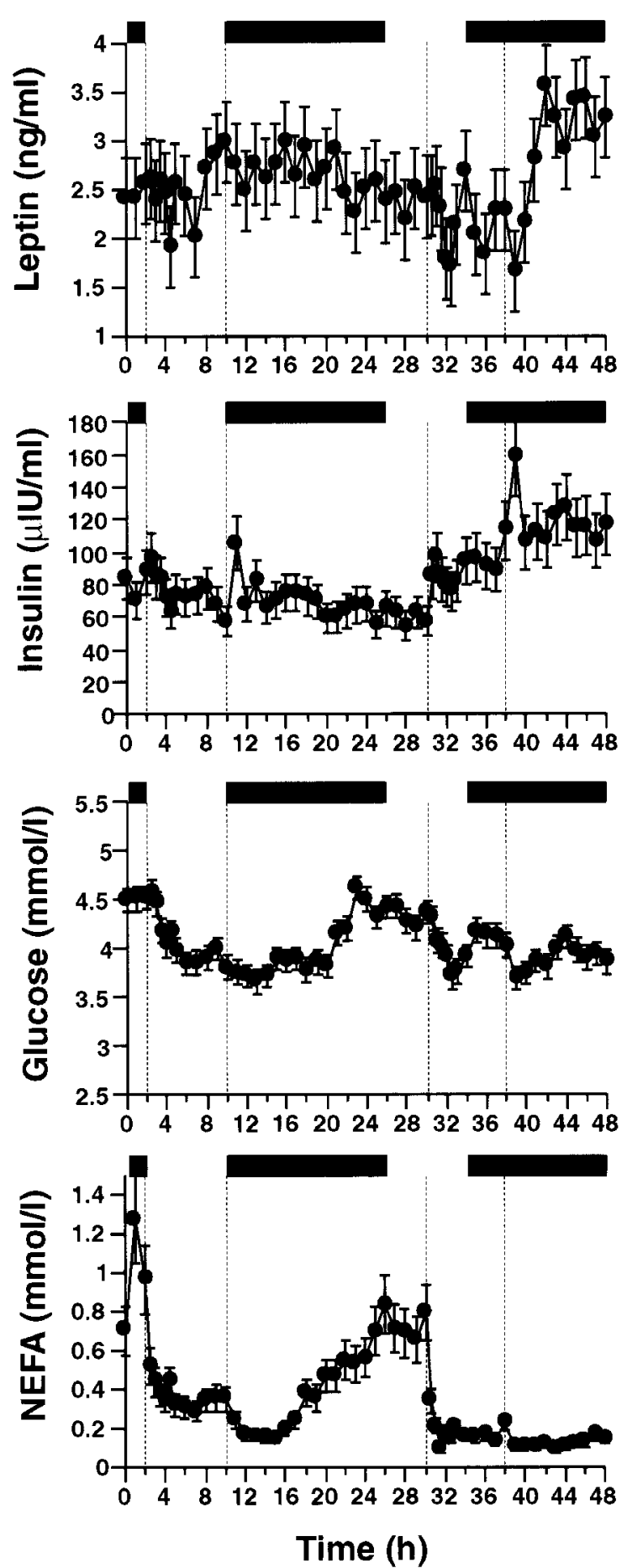

(b) LDR
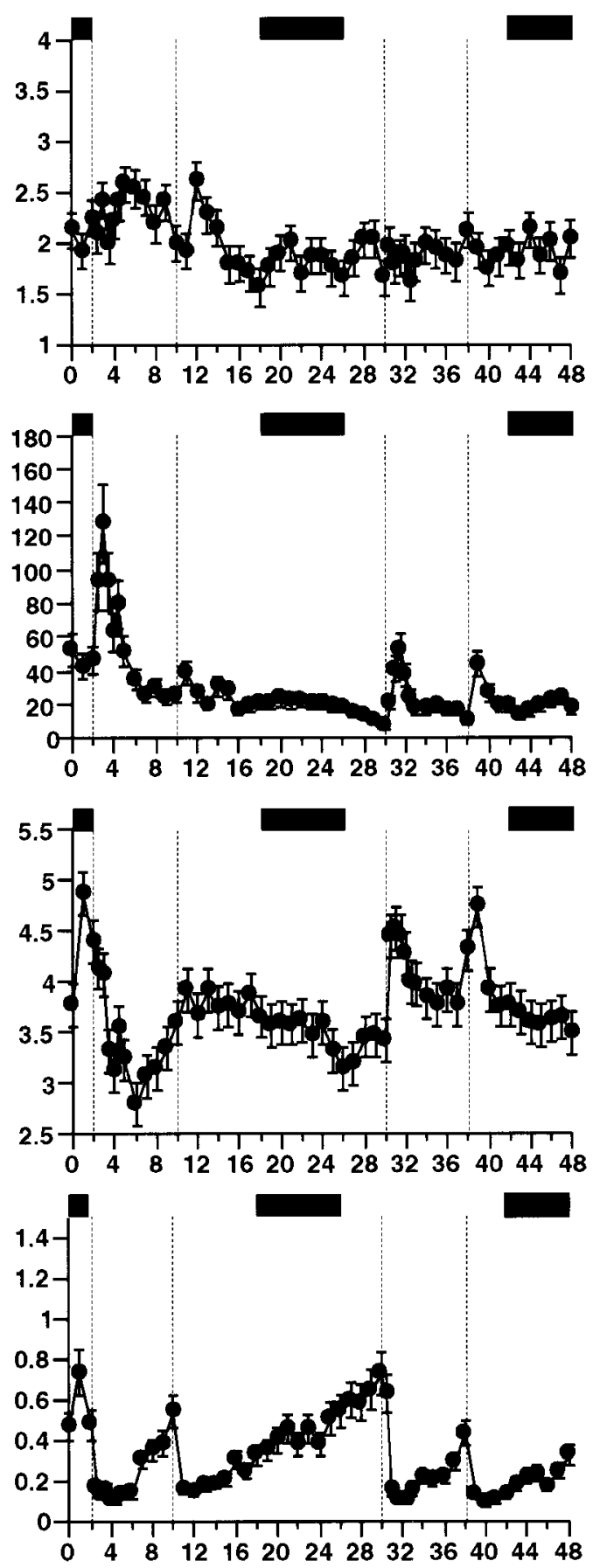

Time (h)

Figure 3 Mean plasma concentrations ( \pm S.E.M.) of leptin, insulin, glucose and NEFA over $48 \mathrm{~h}$ in sheep $(n=6)$ after 16 weeks with freely available food in short days (a) (SD) and after the subsequent 16 weeks with restricted food (90\% liveweight maintenance) in long days (b) (LDR). Meal times (vertical lines) were shifted forwards by $4 \mathrm{~h}$ on day 2 . The solid horizontal bars indicate the periods of darkness. 
(a) SD

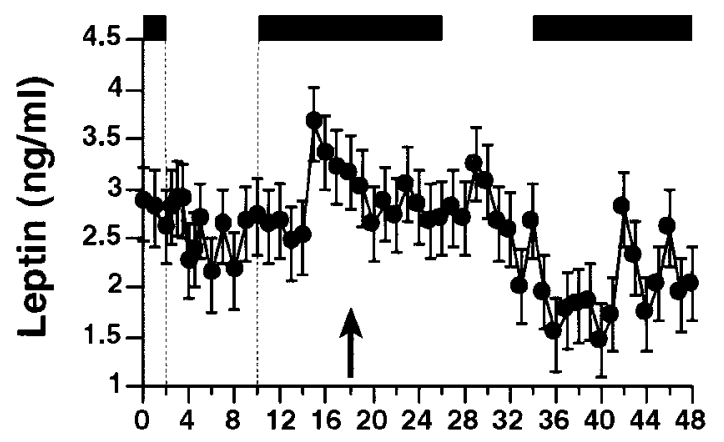

(b) LD
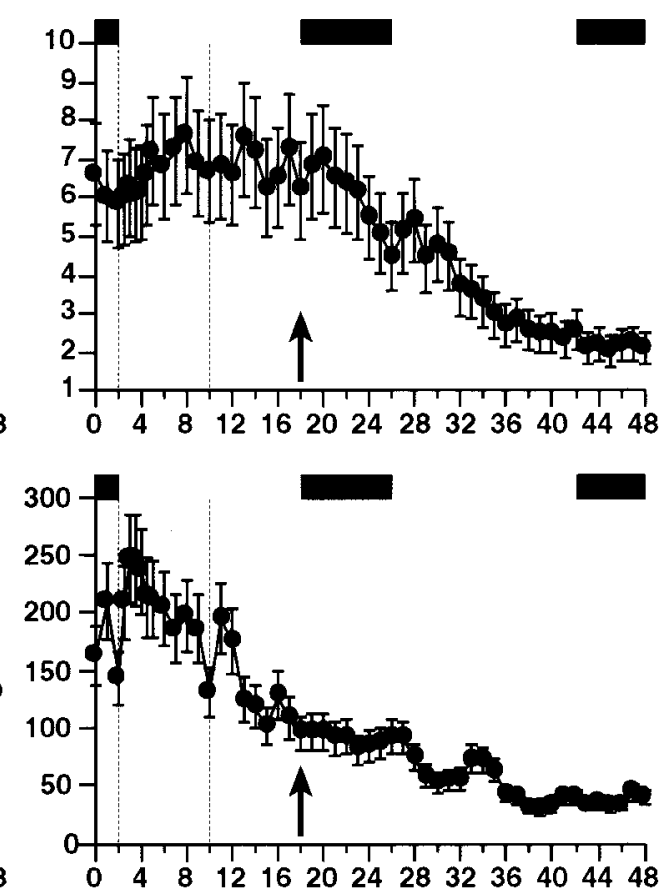
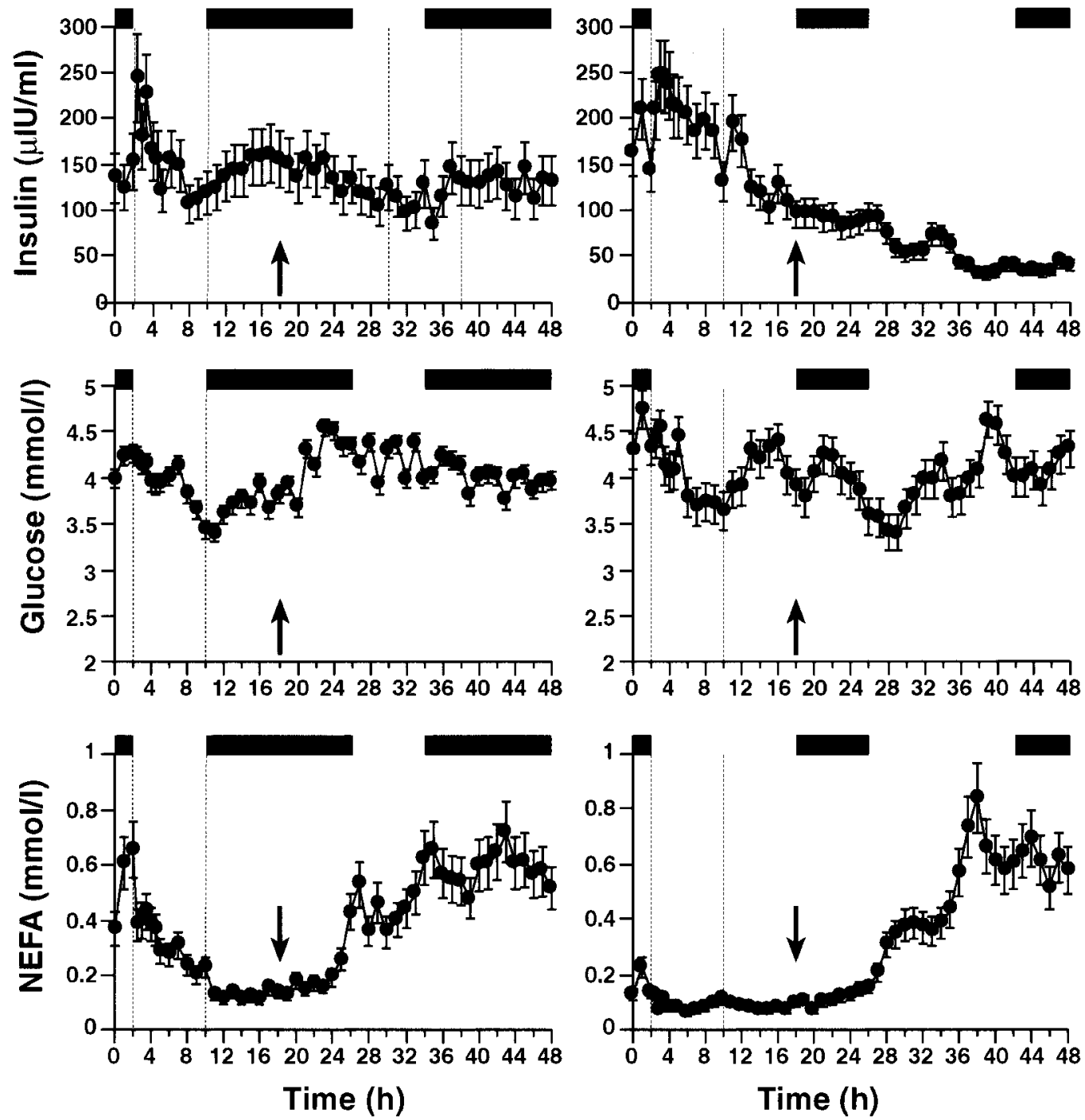

Figure 4 Mean plasma concentrations ( \pm S.E.M.) of leptin, insulin, glucose and NEFA over $48 \mathrm{~h}$ in sheep $(n=6)$ after 16 weeks with freely available food in short days (a) (SD) and after the subsequent 16 weeks with freely available food in long days (b) (LD). Vertical lines indicate meal times on day 1, and all food was removed at $18 \mathrm{~h}$

(indicated by arrow) for the duration of day 2. The solid horizontal bars indicate the periods of darkness. Note scale difference for leptin in LD compared with that in SD. 
Table 2 (a) Mean plasma concentrations ( \pm S.E.M.) of leptin $(\mathrm{ng} / \mathrm{ml}$ ) averaged over three $8 \mathrm{~h}$ periods on day 1 of intensive sampling after 16 weeks with freely available food in short days (SD), after 16 weeks with freely available food in long days (LD) or restricted food (90\% liveweight maintenance) in LDs (LDR), and over equivalent $6-8 \mathrm{~h}$ periods on day 2 following a meal shift in SD and LDR. Meals at $0 \mathrm{~h}$ and $8 \mathrm{~h}$ relative to lights-on on day $1,4 \mathrm{~h}$ and $12 \mathrm{~h}$ on day 2 . Dark period $9-24 \mathrm{~h}$ in SD, 17-24 $\mathrm{h}$ in LD. ANOVA was used to compare periods within photoperiods, using animals as blocks; within rows, a vs b: $P<0 \cdot 01$, c vs d: $P<0 \cdot 001$. (b) Mean cosinor model parameters ( \pm S.E.M.) for the group/days described in (a), and significance of the model: NS, not significant

(a)

Time from lights-on

\begin{tabular}{|c|c|c|c|}
\hline & & & \\
\hline & $1-8 \mathrm{~h}$ & $9-16 \mathrm{~h}$ & $17-24 \mathrm{~h}$ \\
\hline D, day $1(n=12)$ & $2 \cdot 51 \pm 0 \cdot 223^{a}$ & $2 \cdot 84 \pm 0 \cdot 320^{b}$ & $2 \cdot 67 \pm 0 \cdot 274^{\mathrm{ab}}$ \\
\hline LDR, day $1(n=6)$ & $2 \cdot 31 \pm 0 \cdot 127^{c}$ & $1.97 \pm 0.103^{d}$ & $1 \cdot 81 \pm 0 \cdot 129^{d}$ \\
\hline LD, day $1(n=6)$ & $8 \cdot 00 \pm 2 \cdot 241$ & $7 \cdot 90 \pm 1 \cdot 927$ & $7 \cdot 30 \pm 2 \cdot 186$ \\
\hline
\end{tabular}

Time from lights-on

\begin{tabular}{|c|c|c|c|}
\hline & $1-8 \mathrm{~h}$ & $9-16 \mathrm{~h}$ & $17-22 \mathrm{~h}$ \\
\hline & $2 \cdot 28 \pm 0.235^{c}$ & $2 \cdot 32 \pm 0 \cdot 318^{c}$ & $3 \cdot 20 \pm 0 \cdot 447^{d}$ \\
\hline R, day 2 & $1 \cdot 86 \pm 0 \cdot 113$ & $1 \cdot 90 \pm 0 \cdot 106$ & $1.92 \pm 0.097$ \\
\hline
\end{tabular}

(b)

\begin{tabular}{|c|c|c|}
\hline $\begin{array}{l}\text { Amplitude } \\
\text { (ng/ml) }\end{array}$ & $\begin{array}{l}\text { Acrophase } \\
\text { (h) }\end{array}$ & Significance \\
\hline $0.38 \pm 0.09$ & $12 \cdot 2 \pm 1 \cdot 83$ & NS \\
\hline $0 \cdot 34 \pm 0 \cdot 06$ & $4 \cdot 8 \pm 0 \cdot 33$ & $P<0.001$ \\
\hline $0 \cdot 87 \pm 0 \cdot 18$ & $8 \cdot 8 \pm 2 \cdot 25$ & NS \\
\hline $0 \cdot 56 \pm 0 \cdot 14$ & $20 \cdot 1 \pm 0 \cdot 67$ & $P<0.01$ \\
\hline $0 \cdot 13 \pm 0 \cdot 02$ & $14 \cdot 4 \pm 2 \cdot 09$ & NS \\
\hline
\end{tabular}

with all increased in LD as opposed to SD, as is characteristic for this breed (Lincoln \& Richardson 1998, Adam 2000). Plasma leptin concentrations followed these photoperiod-induced changes in adiposity, as reported for another seasonal species, the Siberian hamster (Horton et al. 2000, Klingenspor et al. 2000). However, food restriction in $\mathrm{LD}$ to a level of intake similar to that in SD, and the resultant prevention of liveweight gain, prevented the LD increase in plasma leptin. In contrast to the shorter-term (3 week) study of Bocquier et al. (1998), the present data suggest that the effect of photoperiod on leptin may be secondary to the photoperiod-driven changes in liveweight and adiposity in sheep rather than a direct effect of photoperiod per se.

The effect of food intake restriction, recorded here in LD and not in SD when intake is voluntarily low, was to markedly decrease plasma leptin, in agreement with earlier reports (Bocquier et al. 1998, Delavaud et al. 2000).

It is now apparent that the above observations masked short-term fluctuations of leptin concentrations during the day. These short-term variations were likely to reflect changes in secretion rather than clearance. Leptin is rapidly cleared from the circulation by renal extraction, which is a high capacity, non-saturable process (Cumin et al. 1997, Zeng et al. 1997). Like Blache et al. (2000), we found no evidence for a diurnal rhythm of plasma leptin in sheep occurring independently from the timing of meals, in either photoperiod. Although leptin was elevated at night in SD, the timing of the nocturnal peak was shifted forwards when meal times were shifted forwards, and no such nocturnal rise was seen in LD. Serum leptin levels in men and women show a diurnal pattern (Sinha et al. 1996, Langendonk et al. 1998), but it is equivocal to what extent this is an intrinsic circadian rhythm. The characteristic nocturnal peak occurs during the extended night-time inter-meal interval and during sleep; importantly, the diurnal pattern is modulated by altered patterns of both meal intake (Schoeller et al. 1997, Taylor et al. 1999) and sleep (Simon et al. 1998). Leptin secretion is also highest at night both in rats, associated with night-time feeding (Saladin et al. 1995), and in mice, associated with feeding pattern (Ahren 2000). No nocturnal increase in serum leptin is seen in seasonal Siberian hamsters in either longor short-day photoperiods (Horton et al. 2000). Perhaps the most important determinant of the diurnal pattern of circulating leptin in mammals is feeding behaviour and the timing of food intake.

Here we have evidence for post-prandial plasma leptin 'peaks' in sheep, which were delayed $(2-8 \mathrm{~h})$ relative to the characteristic post-prandial insulin peaks $(0 \cdot 5-1 \mathrm{~h})$, and of low amplitude (15-36\%). Interestingly, the delayed response may not be attributable to the ruminant gut physiology, since meals have been reported to induce a similar leptin response in men (18-26\% increase at 6-8 h; Dallongeville et al. (1998)). The stimulus to increase leptin secretion post-prandially is open to speculation, but the relative changes in other circulating metabolic parameters may provide some clues. In rats there is good evidence that this stimulus may be provided by direct actions of insulin on the adipocyte (Saladin et al. 1995, Hardie et al. 1996), and in mice diurnal variations in circulating leptin and insulin are correlated (Ahren 2000). Although an increase in plasma leptin in sheep has not been seen in response to insulin administration (Kauter et al. 2000, M Marie, S M Rhind \& C L Adam, unpublished observations), these studies may have terminated prematurely $(2$ and $4 \mathrm{~h}$ post-injection respectively) in view of the present findings. The present data are consistent with a positive temporal relationship between plasma insulin and leptin, with increases in insulin preceding by up to $7 \mathrm{~h}$ those of leptin (Figs 3 and 4). During inter-meal intervals, in addition to the positive association between plasma concentrations of leptin and insulin, there was a negative association with NEFA concentrations. These relationships were further exemplified during food deprivation. As observed in rats (Dallman et al. 1999), the decrease in insulin preceded the increase in NEFA, which occurred shortly before or simultaneously with the decrease in leptin (Fig. 4). The changes in NEFA and leptin may have been responses to 
the reduced insulin feedback, or indeed to other signal(s) of negative energy balance. Since both leptin and NEFA are released into the circulation from the same cell type, it is tempting to speculate that leptin secretion is coordinated with triglyceride synthesis within the adipocyte. NEFAs are released when net triglyceride synthesis switches to net breakdown, and this may effectively switch off leptin secretion, since intracellular elevation of free fatty acids in rat adipocytes has been shown to inhibit leptin secretion (Shintani et al. 2000). Conversely, increased leptin secretion may be linked with lipogenesis. The basal circulating concentrations of leptin (in starved or LDR sheep) remained above the detection limit of the assay, suggesting that there exists both a basal level of leptin secretion, which is insensitive to proximate fluctuations in food intake, and a higher level of leptin secretion which is sensitive to food intake.

Reduced leptin secretion following $48 \mathrm{~h}$ food deprivation has been reported previously for ruminants (sheep: Kumar et al. 1998, cattle: Amstalden et al. 2000), yet the time course of the decrease has not been studied to date. Here, we report a rapid decline in plasma leptin during food deprivation in sheep, effective from the time of the first missed meal and reaching basal levels within $24 \mathrm{~h}$ of the last meal, regardless of adiposity. This is an important demonstration of the 'dual control' of circulating leptin in a ruminant; whereas background concentrations in the fed animal generally reflect adiposity, there is superimposed an acute sensitivity to short-term alterations in food intake.

In conclusion, plasma leptin concentrations in sheep were clearly sensitive to long-term photoperiod-driven changes in body weight, adiposity and food intake, but also to the short-term changes in energy balance that occurred both as a function of meal intake and as a result of food deprivation. There was no evidence for an independent effect of photoperiod or for a diurnal rhythm of plasma leptin in sheep. A strong association between leptin and insulin and NEFA was suggested, but no clear relationship with circulating glucose. However, any putative roles of insulin and NEFA in controlling leptin secretion remain unresolved. Finally, although the magnitude of the daily fluctuations in plasma leptin were small, single samples taken in longitudinal studies should clearly be taken at a standardised time post-prandially to be representative, and not during fasting. These data provide clear evidence of the sensitivity of leptin to short-term alterations in food intake in sheep, contrary to the hypothesis that a ruminant physiology would dampen such effects. Thus sheep, like rodents, apparently experience two distinct forms of leptin feedback, one encoding body fat reserves and the second signalling short-term changes in food intake.

\section{Acknowledgements}

We thank the following for their help with this study: A Gertler (for the generous gift of recombinant ovine leptin),
N Hoggard (leptin antibody), T Atkinson (iodinations), M Annand (NEFA and glucose analyses), D Miller and Z Archer (overnight blood sampling), and D MacPherson and his staff (routine animal care). Special thanks go to G Horgan (BioSS) for help with statistical analyses. The work was funded by the Scottish Executive Rural Affairs Department.

\section{References}

Adam CL 2000 Nutritional and photoperiodic regulation of appetite and reproduction in seasonal domestic mammals. Reproduction in Domestic Animals Supplement 6 1-8.

Ahima RS \& Flier JS 2000 Leptin. Annual Review of Physiology 25 413-427.

Ahren B 2000 Diurnal variation in circulating leptin is dependent on gender, food intake and circulating insulin in mice. Acta Physiologica Scandinavica 169 325-331.

Amstalden M, Garcia MR, Williams SW, Stanko RL, Nizielski SE, Morrison CD, Keisler DH \& Williams GL 2000 Leptin gene expression, circulating leptin, and luteinizing hormone pulsatility are acutely responsive to short-term fasting in prepubertal heifers: relationships to circulating insulin and insulin-like growth factor I. Biology of Reproduction 63 127-133.

Blache D, Tellam RL, Chagas LM, Blackberry MA, Vercoe PE \& Martin GB 2000 Level of nutrition affects leptin concentrations in plasma and cerebrospinal fluid in sheep. Journal of Endocrinology 165 625-637.

Bocquier F, Bonnet M, Faulconnier Y, Guerre-Millo M, Martin P \& Chilliard Y 1998 Effects of photoperiod and feeding level on perirenal adipose tissue metabolic activity and leptin synthesis in the ovariectomized ewe. Reproduction, Nutrition, Development $\mathbf{3 8}$ 489-498.

Considine RV, Sinha MK, Heiman ML, Kriauciunas A, Stephens TW, Nyce MR, Ohannesian JP, Marco CC, McKee LJ, Bauer TL \& Caro JF 1996 Serum immunoreactive-leptin concentrations in normal-weight and obese humans. New England Journal of Medicine 334 292-295.

Cumin F, Baum HP \& Levens N 1997 Mechanism of leptin removal from the circulation by the kidney. Journal of Endocrinology 155 577-585.

Dallman MF, Akana SF, Bhatnagar S, Bell ME, Choi SJ, Chu A, Horsley C, Levin N, Meijer O, Soriano LR, Strack AM \& Viau V 1999 Starvation: early signals, sensors, and sequelae. Endocrinology 140 4015-4023.

Dallongeville J, Hecquet B, Lebel P, Edme JL, le Fur C, Fruchart JC, Auwerx J \& Romon M 1998 Short term response of circulating leptin to feeding and fasting in man: influence of circadian cycle. International Journal of Obesity 22 728-733.

Delavaud C, Bocquier F, Chilliard Y, Keisler DH, Gertler A \& Kann G 2000 Plasma leptin determination in ruminants: effect of nutritional status and body fatness on plasma leptin concentration assessed by a specific RIA in sheep. Journal of Endocrinology 165 519-526.

Ehrhardt RA, Slepetis RM, Siegal-Willott J, Van Amburgh ME, Bell AW \& Boisclair YR 2000 Development of a specific radioimmunoassay to measure physiological changes of circulating leptin in cattle and sheep. Journal of Endocrinology 166 519-528.

Genstat 5 Committee 1993 Genstat 5 Release 3 Reference Manual. Oxford: Clarendon Press.

Gertler A, Simmons J \& Keisler DH 1998 Large-scale preparation of biologically active recombinant ovine obese protein (leptin). FEBS Letters 422 137-140.

Hardie LJ, Rayner DV, Holmes S \& Trayhurn P 1996 Circulating leptin levels are modulated by fasting, cold exposure and insulin 
administration in lean but not Zucker $(\mathrm{fa} / \mathrm{fa})$ rats as measured by ELISA. Biochemical and Biophysical Research Communications 223 660-665.

Horton TH, Buxton OM, Losee-Olson S \& Turek FW 2000 Twenty-four-hour profiles of serum leptin in Siberian and golden hamsters: photoperiodic and diurnal variations. Hormones and Behavior 37 388-398.

Hunter WM \& Greenwood FC 1962 Preparation of iodine-131 labelled human growth hormone of high specific activity. Nature 194495.

Kauter K, Ball M, Kearney P, Tellam R \& McFarlane JR 2000 Adrenaline, insulin and glucagon do not have acute effects on plasma leptin levels in sheep: development and characterisation of an ovine leptin ELISA. Journal of Endocrinology 166 127-135.

Klingenspor M, Niggeman H \& Heldmaier G 2000 Modulation of leptin sensitivity by short photoperiod acclimation in the Djungarian hamster (Phodopus sungorus). Journal of Comparative Physiology B $\mathbf{1 7 0}$ $37-43$.

Kumar B, Francis SM, Suttie JM \& Thompson MP 1998 Expression of obese mRNA in genetically lean and fat selection lines of sheep. Comparative Biochemistry and Physiology B 120 543-548.

Langendonk JG, Oijl H, Toornvliet AC, Burggraaf J, Frolich M, Schoemaker RC, Doornbos J, Cohen AF \& Meinders AE 1998 Circadian rhythm of plasma leptin levels in upper and lower body obese women: influence of body fat distribution and weight loss. Journal of Clinical Endocrinology and Metabolism 83 1706-1712.

Lincoln GA \& Richardson M 1998 Photo-neuroendocrine control of seasonal cycles in body weight, pelage growth and reproduction: lessons from the HPD sheep model. Comparative Biochemistry and Physiology C 119 283-294.

Littell RC, Henry PR \& Ammerman CB 1998 Statistical analysis of repeated measures data using SAS procedures. Journal of Animal Science 76 1216-1231.

MacRae JC, Bruce LA, Hovell FDDeB, Hart IC, Inkster J, Walker A \& Atkinson T 1991 Influence of protein nutrition on the response of growing lambs to exogenous bovine growth hormone. Journal of Endocrinology 130 53-61.

Maffei M, Halaas J, Ravussin E, Pratley RE, Lee GH, Zhang Y, Fei H, Kim S, Lallone R, Ranganathan S, Kern PA \& Friedman JM 1995 Leptin levels in human and rodent: measurement of plasma leptin and ob RNA in obese and weight-reduced subjects. Nature Medicine 1 1155-1161.
Mardia KV 1972 Statistics of Directional Data. London, New York: Academic Press.

Matsubara C, Nishikawa Y, Yoshida Y \& Takamura K 1983 A spectrophotometric method for the determination of free fatty acids in serum using acyl-coenzyme A synthetase and acyl-coenzyme A oxidase. Analytical Biochemistry $130128-133$.

Peterson JI \& Young DS 1968 Evaluation of the hexokinase/glucose6-phosphate dehydrogenase method of determination of glucose in urine. Analytical Biochemistry 23301.

Russel AJF, Doney JM \& Gunn RG 1969 Subjective assessment of body fat in live sheep. Journal of Agricultural Science 72 451-454.

Saladin R, De Vos P, Guerre-Millo M, Leturque A, Girard J, Staels B \& Auwerx J 1995 Transient increase in obese gene expression after food intake or insulin administration. Nature 377 527-529.

Schoeller DA, Cella LK, Sinha MK \& Caro JF 1997 Entrainment of the diurnal rhythm of plasma leptin to meal timing. Journal of Clinical Investigation 100 1882-1887.

Shintani M, Nishimura H, Yonemitsu S, Masuzaki H, Ogawa Y, Hosada K, Inoue G, Yoshimasa Y \& Nakao K 2000 Downregulation of leptin by free fatty acids in rat adipocytes: effects of triacsin C, palmitate, and 2-bromopalmitate. Metabolism 49 326-330.

Simon C, Gronfier C, Schlienger JL \& Brandenberger G 1998 Circadian and ultradian variations of leptin in normal man under continuous enteral nutrition: relationship to sleep and body temperature. Journal of Clinical Endocrinology and Metabolism $\mathbf{8 3}$ 1893-1899.

Sinha MK, Ohannesian JP, Heiman ML, Kriauciunas A, Stephens TW, Magosin S, Marco C \& Caro JF 1996 Nocturnal rise of leptin in lean, obese, and non-insulin-dependent diabetes mellitus subjects. Journal of Clinical Investigation 97 1344-1347.

Taylor AE, Hubbard J \& Anderson EJ 1999 Impact of binge eating on metabolic and leptin dynamics in normal young women. Journal of Clinical Endocrinology and Metabolism 84 428-434.

Zeng J, Patterson BW, Klein S, Martin DR, Dagogo-Jack S, Kohrt WM, Miller SB \& Landt M 1997 Whole body leptin kinetics and renal metabolism in vivo. American Journal of Physiology 273 E1102-E1106.

Revised manuscript received 12 February 2001 Accepted 1 March 2001 